\title{
STUDENTS' PARTICIPATION IN ONLINE LEARNING DURING COVID-19 PANDEMIC IN EAST PRIANGAN
}

\author{
Yuyun Nuriyah Muslih', Imas Komalasari'2, Ai Hilyatul Halimah ${ }^{3}$ \\ 1,2,3STAINU Tasikmalaya \\ 1,2,3Jalan Argasari No.13, Cihideung, Kota Tasikmalaya \\ Email: yuyunnuriyahmuslih@gmail.com ${ }^{1}$, imaskomalasari343@gmail.com², \\ aihilyatulhalimah@gmail.com ${ }^{3}$
}

\begin{abstract}
:
Participation in learning is used as a means to create effective learning to achieve learning success. Likewise, with online learning, participation has an important position that students must have. The form of learning participation can be realized in visual, oral, listening, writing and mental activities. The purpose of the study was to determine the level of student participation in online learning during the Covid-19 pandemic. The research population was all students in East Priangan, and the sample selected was 85 students who live in East Priangan. The research method used was survey research with a quantitative approach and data collection techniques through distributing questionnaires to the sample consisting of 85 students and indirect interviews. The research results indicated that online learning during the Covid-19 pandemic could be an effective way to be implemented, although, in practice, there were still some technical and non-technical obstacles.
\end{abstract}

\begin{abstract}
Abstrak:
Partisipasi dalam pembelajaran digunakan sebagai sarana untuk menciptakan pembelajaran yang efektif guna mencapai keberhasilan belajar. Begitu pun dengan pembelajaran online, partisipasi memiliki posisi penting yang harus dimiliki mahasiswa. Bentuk partisipasi belajar dapat diwujudkan dalam aktivitas visual, oral, menyimak, menulis dan mental. Tujuan penelitian adalah untuk mengetahui tingkat partisipasi mahasiswa dalam perkuliahan online di masa pandemi Covid-19. Populasi penelitiannya adalah seluruh mahasiswa yang ada di Priangan Timur, dengan sampel yang digunakan yaitu 85 mahasiswa yang berdomisili di Priangan Timur. Adapun metode penelitiannya menggunakan penelitian survei dengan pendekatan kuantitatif dan teknik pengumpulan datanya melalui penyebaran kuisioner kepada sample yang terdiri dari 85 mahasiswa dan wawancara tidak langsung. Hasil penelitian menunjukan bahwa perkuliahan online di masa pademi Covid-19 dapat dikatakan sebagai cara yang efektif untuk dilaksanakan, meskipun dalam pelaksanaannya masih ditemui adanya beberapa kendala baik teknis maupun non teknis.
\end{abstract}

Keywords:

Students' Participation, Online Learning, Covid-19 Pandemic

How to Cite: Muslih, Y. N., Komalasari, I., \& Haimah, A. H. (2021). Students' Participation in Online Learning During Covid-19 Pandemic in East Priangan. Lentera Pendidikan : Jurnal Ilmu Tarbiyah dan Keguruan, 24(2), 276-289. https://doi.org/10.24252/lp.2021v24n2i10. 


\section{INTRODUCTION}

Corona Virus Disease-19 (Covid-19) or known as the Coronavirus, is a health crisis that has now changed almost the entire order of life. After the World Health Organization (WHO) established the virus as a pandemic, its spread almost reached more than 100 countries globally. The spread of the Coronavirus has caused significant impacts in various sectors of life, including health, society, economy, education, and others.

One area that is also exposed to the Coronavirus is the field of education. On May 6, 2020, the United Nations Educational, Scientific and Cultural Organization (UNESCO) noted that most governments worldwide have temporarily closed various educational institutions in their countries. That effort was to contain the spread of the COVID-19 pandemic. The national closure affected approximately $72.4 \%$ of world students (UNESCO, 2020). Likewise with Indonesia, exposure to the Coronavirus has had severe consequences on the world of education, so that the government does not hesitate to take a policy issued by the Ministry of Education and Culture called Kemendikbud with the issuance of circular number 42020 concerning the implementation of educational policies in the future. The emergency of the spread of Corona Virus Disease (COVID-19), one of the contents of the policy states an appeal to carry out the learning process from home through online/distance learning (Kemendikbud, 2020).

Higher education as an education provider unit has an essential role in helping the government and society break the chain of the spread of the Coronavirus, namely by carrying out social restrictions through the implementation of learning and working online from home. With this policy, it is hoped that it can be the best solution for lecturers in carrying out their obligations towards fulfilling students' rights to learn and acquire knowledge during a pandemic.

In the world of higher education, learning activities are very important for a student. The knowledge obtained by students is obtained from the learning process, not transferred from lecturers to students (constructivism learning). Learning is defined as the interaction between educators (lecturers) and students, which are done consciously, planned both indoors and outdoors to improve student abilities. Thus, interaction and active participation in the learning process are significant so that there is an increase in student abilities.

The vital thing expected from learning outcomes is a change for the better. A student who carries out learning activities will be seen in his/her behavior, namely that there are changes in either one or several aspects resulting from learning outcomes. The aspects include knowledge, understanding, habits, skills, appreciation, emotional, social, physical, ethical, or ethical relationships, and attitude aspects (Afandi, Chamalah, \& Wardani, 2013).

Every learning activity carried out is expected to be able to create effective learning to achieve successful learning. According to Abdullah, Bakar, and Mahbob (2012), An effective learning process occurs when educators and their students interact and participate in learning activities. A participatory learning process will encourage the mutual exchange of information, stimulate interest, and respect recognition between educators and students. 
Student participation has an essential role in learning success. The existence of active student participation can achieve learning goals so that students have been better academic achievement (Safrida, Ambarwati, \& Albirri, 2017). To achieve learning success, several factors influence, including (1) the level of mastery of knowledge obtained by students from previous lectures can have an impact on active participation in classes; and (2) the availability of available and supportive facilities and infrastructure, especially when participants will carry out learning activities, such as the availability of learning media for books, laptops/computers and others (Dika \& Sylejmani, 2012).

In addition to these supporting factors, there were also inhibiting factors obtained from interviews with 85 students in East Priangan. Firstly, lack of data and internet packages. Secondly, some students do not have their own laptop/computer and smartphones that do not support internet access (less sophisticated). Thirdly, some students have not realized and implemented etiquette or internet etiquette. Those problems can be seen in the video conferencing process, such as forgetting to turn off the microphone and not paying attention to the presentation or other speakers. Fourthly, the implementation of a video conference is also constrained by limited internet bandwidth so that not all students can directly connect when there is a video conference session. Fifthly, the internet network is still weak in student residences. Sixthly, lecturers do not understand students who come from various backgrounds and diverse personality conditions. Seventhly, lack of responsibility and strong self-control from students when using learning media, social media platforms and the like. Such things can be a source of distraction and distract from expected learning and academic achievement (Abdillah, 2020; Ali, Iskandar, Amin, \& Langove, 2017; Anhusadar, 2020; Najib, 2017).

The existence of various supporting and inhibiting factors in online learning is an important thing that needs to be considered in growing and awakening student participation in online learning. According to Paul D Dierich in Sardiman (2011), participation activities in the learning process can be classified into two parts: physical and psychological activities. Physical activity is an active state shown by students by involving limbs, making things, playing or working in learning activities. Meanwhile, psychic activity is the mental power of students in doing a lesson with as much or many functions as possible to get optimal teaching and follow it actively.

In detail, the aspects of physical and psychological activity referred to by Paul D Dierich in Sardiman (2011) include: (a) Visual activities: reading and paying attention; (b) Oral activities: stating, formulating, asking, giving suggestions, issuing opinions, interviews, discussions, interruptions, and so on; (c) Listening activities: listening to descriptions, conversations, discussions; (d) Writing activities: writing, copying. (e) Drawing activities: drawing, making graphs, maps, and so on; (f) Motor activities: conducting experiments, making models; (g) Mental activities: consider, remember, solve problems, analyze, see relationships, make decisions; (h) Emotional activities: interested, bored, happy, calm, and so on.

Based on the background described, learning participation is an important thing that students must own, especially in online learning. However, in practice, it cannot be denied 
that there are various obstacles they face. So based on this data, researchers are encouraged to analyze the level of student participation in online lectures during the COVID-19 pandemic.

\section{RESEARCH METHOD}

The type of research used in this research is survey research with a quantitative approach (Quantitative Research), namely a study that takes a sample from one population and uses a questionnaire as the primary data collection tool (Samsudi, 2009). The survey used in this study intends to describe the research findings related to the learning participation of East Priangan students in online learning.

The data collection technique was done through questionnaires and indirect interviews. In the implementation, the questionnaires used the Google Forms application and interviews were not directly conducted face-to-face but online via telephone to obtain information related to students' attitudes and perceptions regarding implementing online lectures during the COVID-19 pandemic. Interviews were done to 85 students who live in East Priangan (Sumedang, Garut, Tasikmalaya, and Ciamis). The question type asked were structured and unstructured questions related to effectiveness and obstacles during online classes during the covid-19 pandemic.

The data collection through questionnaires was used as a research instrument to determine student learning participation in online lectures with the help of the Google Forms application. In its implementation, research subjects were asked to fill out an instrument that contained a list of statements that had been given a choice of answers, then put a mark on the available answers according to their beliefs. The questionnaire instrument used was a Likert scale with Always, Very Often, Often, Rarely, and Never of choices. The number of statement items in the questionnaire is 34 statements. The population used in this study were all students who live in Priangan, while the sample selected was 85 students from East Priangan (Sumedang, Garut, Tasikmalaya, and Ciamis). The steps taken in the research, namely starting with designing research instruments, then conducting reliability validation tests, is because, in survey research, a valid and reliable instrument is a must so that the data obtained shows the actual situation. In this study, the validity and reliability of the instrument were tested using the SPSS 16.0 program, and the alpha coefficient value was 0.873 , and the table $r$ value was 0.444 . Thus, the calculated alpha value was greater than the table $r$ value $(0.873>0.444)$, which meant that the questionnaire instrument was declared reliable and could be used as a data collection tool. In addition to the reliability validity test, an instrument readability test was also conducted, given to 4 students deemed to have high and low learning participation. It was done to obtain accurate data. Furthermore, the instrument that had been validated was distributed to the respondents, and then the results were analyzed using descriptive statistical techniques.

In describing the objectives to be achieved in the study, certain criteria were used that refer to the average score of the questionnaire category obtained by the respondent. The category score used was adapted from the five score categories developed on a Linkert 
scale (Muhidin \& Abdurahman, 2007). These criteria can be seen in the table 1.

Table 1. Criteria for Analysis Description

\begin{tabular}{cc}
\hline Score Range & $\begin{array}{c}\text { Interpretation } \\
\text { Category }\end{array}$ \\
\hline $1.00-1.79$ & Very Low \\
\hline $1.80-2.59$ & Low \\
\hline $2.60-3.39$ & Moderate \\
\hline $3.40-4.19$ & High \\
\hline $4.20-5.00$ & Very High \\
\hline
\end{tabular}

\section{RESULTS AND DISCUSSION}

\section{Activities in Participatory Learning}

Participation is required in learning because the optimal learning process will be achieved if students can participate responsibly in the learning process. Likewise, online learning is often more motivated because the learning environment usually relies on motivation and the associated characteristics of curiosity and self-regulation to engage the learning process.

There is no learning without activity. In this regard, according to Abdullah, Bakar, and Mahbob (2012), an effective learning process occurs when students and educators (lecturers) can interact and participate in learning activities. Activeness in the form of attitudes/behaviors shown by students in learning is one form of participation in education, such as listening, responding, discussing, reading, writing, and others. With the active participation of students in lectures, it is hoped that it can help achieve learning goals to have a better academic achievement (Safrida, Ambarwati, \& Albirri, 2017).

This study aimed to investigate the level of student participation in online learning during the COVID-19 pandemic. Regarding this objective, it could be seen from students' participation in activities carried out in real terms to improve their abilities as a form of the totality of the learning process. It involved students mentally and emotionally to contribute and be responsible for achieving results and satisfying learning. In detail, to find out the level of student participation in online learning, the description of learning activities describe below:

\section{Visual Activity and Emotional Condition}

In this category, student learning participation activities can be seen from the activities carried out by students both in reading and viewing course material or student attendance at each lecture. The description of this was described as follows:

Reading and Reviewing Books/Lecture Materials

Reading is one of the learning activities that students can do. In general, students' learning activities are carried out on campus/college. However, during the Covid-19 pandemic, all learning activities could not be done anywhere but preferably done at home, either online or offline. Likewise, with reading, this activity is one of the supporting factors for students' success in online learning. 
The study results found that during online learning, most of the students, or $47.1 \%$ of all respondents, only read and saw material during lectures. In comparison, $64.7 \%$ of students rarely activated themselves to read books before the class started. Likewise, after the course, $55.85 \%$ of students rarely read or looked back at the material delivered in lectures. The main cause of this condition was because students rarely had an interest in reading lecture books. In addition, based on indirect interviews, information was also obtained that the lack of teaching resources such as reference books, diktats or textbooks recommended by lecturers became one of the triggers for the lack of interest in reading. Thus, in general, reading books by students in online lectures obtained 2.66 of average score and emotional condition in reading obtained 2.57. If the average scores obtained were calculated, students' visual activity and emotional condition in reading books were 2.61 or moderate.

The findings of this study provide information that students' reading activities were moderate. In its implementation, most of the students (respondents) often do reading activities during lectures. In contrast, they rarely did it before and after lectures. They emotionally had a low reading interest. Responding to these findings, according to Kamah, Rachmanata, and Rachmanata (2002), interest in reading is the presence of attention or liking (the tendency of the interest) to read. Attention or love to reading needs to be nurtured, directed, and developed from early childhood to adulthood.

Reading activities can smoothly run if accompanied by interest. Students who have an interest in reading textbooks (lecture material) will affect their learning outcomes. Because if they do not have an interest in reading about the lecture material, students will not study seriously and will not get satisfaction and results from the lecture material being taught (Muslih, Wibowo, \& Purwanto, 2017). Furthermore, students' interest in reading will motivate them to be actively involved in lectures because it can be expressed through a statement that shows that the individual likes one thing more than another. Besides, interest can also be manifested through participation in an activity. Individuals who have an interest in a particular subject tend to pay more attention to that subject. Based on this, interest in reading activities is very important. It needs to be developed and improved because it attempts to help students see how the relationship between the material they are expected to study and themselves as individuals. This process shows students how specific knowledge or skills can affect them, serve their goals, and satisfy their needs. If students realize that reading is a tool to achieve several goals that they consider essential and see that the results of their reading experience will lead to self-improvement, they will likely be interested in reading activities (Slamet, 2003).

\section{Attendance}

Attendance is a condition that allows teaching and learning interactions to occur (Prihatin, 2014). With the presence of students in lectures, it is also possible to be actively involved in these interactions. For most lecturers, this is used as an important part of providing an assessment of their students.

In online lectures that had been carried out so far, the results indicated that during lectures, students always try to be able to attend/follow lectures. It could be seen from the 
percentage results obtained that $81.2 \%$ of students always took the time to attend lectures while the average score was 4.69 . When consulted with the interpretation scale of the average score of respondents' answers, the presence of students in online lectures was generally in the Very Good category. However, even though most of the students were able to attend lectures, from the results of the percentage of student answer scores, it was also found that around $52.9 \%$ of students complained about the obstacles (difficulties) they experienced to attend and take online lectures. The average was 4.17, which meant that, in general, the barriers experienced by students to attend lectures were in the High category. Some of these obstacles included: (1) lack of data and internet packages; (2) some students did not have their own laptop/computer and smartphones that support internet access (less sophisticated); (3) the implementation of video conference was also constrained by limited internet bandwidth, so that not all students could connect directly when there was a video conference session; (5) The internet network was still weak in students' residences; (6) students were not fit (sick); (7) there were problems in the family environment that were very important and involve students; (8) the death of a close relative or neighbor; (9) the presence of a sick family; (10) forgetting the lecture schedule; (11) Morals were not good; (12) truant; (13) lack of facilities from universities such as: internet supports and others; (14) lack of guidance or motivation from supporting lecturers who should both lecturers and students show high enthusiasm in each learning process because motivation and enthusiasm for learning have a close relationship (Abdillah, 2020; Anhusadar, 2020; Ali, Iskandar, Amin, \& Langove, 2017; Fitriyani, Fauzi, \& Sari, 2020; Najib, 2017; Prihatin, 2014). Meanwhile, if the value of reading activity and student attendance in lectures were calculated, it was obtained 3.04 of the average value. In general, the condition of students' visual activities in lectures was in the Moderate category.

Based on the study results, attendance in online lectures needs to get attention from all parties, both from students, parents, the environment or institutions/colleges. As stated by Dohaney, Róiste, Salmon, \& Sutherland (2020) that support, community, leadership, and planning at universities were very important in building, increasing resilience and preventing disruptions to university teaching, including attendance.

\section{Speaking (verbal) Activity and Emotional Condition}

We can see the category of verbal activities in lectures from several activities, such as: asking questions, arguing, arguing, or providing suggestions in discussions or the continuation of the class. In general, students' verbal activity in online learning showed that almost $41.2 \%$ of students rarely asked questions in lectures. In addition, in the activity of refuting, arguing and giving advice, $49.5 \%$ of students very often denied, argued or advised in classes. However, when viewed from the quality of argument contents, rebuttals and also suggestions given by students, it was obtained $49.9 \%$. It indicated that students rarely thought about or adjusted what was being discussed with the content of the material discussion. From this description, the average score of student speaking activity in lectures was 3.27 or was in the moderate category. In addition, it was also found that in carrying out verbal activities, almost $47.1 \%$ of students did not get significant emotional barriers. 
In other words, they had good courage in speaking or oral activities in lectures. Meanwhile, if seen from the average score, it was 3.87, which meant that the students' courage in speaking was in the high category. Then, if each average score obtained from the speaking activity and emotional condition were calculated, the average score was 3.44. It indicated that students' verbal activities in lectures were in the high category.

Based on this research, the results showed that in the speaking (verbal) activity carried out by students in the learning process, almost half of students rarely ask questions. Still, they preferred to argue and provide suggestions. However, when viewed from the argument content qualities given by students in lectures, students rarely thought about or adjusted what was being discussed with the material's content. However, in this case, the courage they have to speak or take oral activities in lectures is in a Good category.

Speaking is a skill to convey someone's ideas to others. In fact, in the world of education, speaking plays an important role as a means of scientific thinking, which can be realized through the ability to think critically, argue, master the language, and broad general knowledge. This skill can be obtained and mastered by increasing practice. Mastering general knowledge can be obtained by reading books, journals, magazines, newspapers, internet access, etc. Meanwhile, critical thinking and arguing can be developed through good academic habituation (Nawawi, Qura, \& Rahmayanti, 2017).

\section{Listening Activity and Emotional Condition}

Students listening to lectures with great attention and appreciation could be seen from the discussion that they did during learning activities. In general, this activity can be seen from the research results showed that $35.3 \%$ of students tried to always listen to the explanation of the material delivered. The average score was 3.47, or the High category. In addition, $26.45 \%$ of students also often felt happy when listening to a lecture with 3.06 of the average score, which meant that the emotional condition or feeling of pleasure felt by students when listening to the material was at a Moderate level. If the overall average scores obtained from the general description of the listening activity and students' emotions when listening to the material were calculated, the average score was 3.26. In other words, listening activities in lectures were in the Moderate category.

Based on the research findings, information was obtained in detail that most students tried to always listen to the explanation of the material presented. They emotionally felt happy when listening to the delivered lecture. Responding to these findings, according to Tarigan (Daeng, Amir, \& Hamsa, 2010), listening is a process of listening to spoken symbols with full attention, understanding, appreciation, and interpretation to obtain information capturing the content or message and understanding the communication that the speaker has conveyed through spoken language.

Listening in the world of education, especially in higher education, has an essential role because by listening, students can get information to increase knowledge, accept and respect others' opinions. Listening is an intentional and planned activity to achieve a goal (Daeng, Amir, \& Hamsa, 2010). Therefore, it is necessary for students to instill the importance of the material presented by the speaker in their future life, so that they can listen to and follow each lecture material well. 


\section{Writing Activity and Emotional Condition}

Writing is one part of participatory activities in the learning process. In general, the conditions for students' writing in online lectures could be done by re-copying the material presented in the class, writing misunderstood material, and writing things considered important in lectures.

The study results explained that $48.5 \%$ of the total respondents rarely did writing activities for the materials presented in lectures. The average score obtained from writing activities was 2.59, which indicated that students' writing activities in lessons are Moderate level. In fact, $41.2 \%$ of students felt that they rarely have an interest in writing or other words, the material presented in lectures did not need to be recorded or copied back into books but rather stored in applications or sophisticated gadgets such as computers, laptops, or smartphones that used during lectures. In addition, $30.6 \%$ of students complained that they often felt bored writing lecture material. The average score was 2.92 or Moderate level. If the conditions of writing activities and emotional conditions when writing were calculated, the average score was 2.76 , which interpreted that the condition of students' writing activities, in general, was Moderate category.

This research indicated that students' writing activities, especially in writing the materials presented in lectures, were still relatively rare. Many students lack interest in writing or felt bored to write, so they preferred not to write learning materials in notebooks and choose to save them in applications or sophisticated gadgets or digital devices.

Basically, in the educational process, writing has a very important portion. Someone does writing as a form of indirect communication which is done by transferring thoughts or feelings by utilizing graphology, language structure, and vocabulary by using symbols so that they can be read. Through reading the results of these writings, one's insight into knowledge will continue to increase, intelligence will continue to be sharpened, which in turn will determine a person's behavior (Syarif, Zulkarnaini, \& Sumarno, 2009). In addition, according to Shin (2014), an individual who reads a writing book will have the freedom to interpret the available information according to his/her thoughts and understanding. He or she can imagine certain situations in his mind, and the impact of this process will develop the individual's thinking ability. It is different when reading activities are no longer through books/writings but are carried out through applications or digital devices. Although digital devices can provide convenience and provide all the information/knowledge desired, in the process, individuals cannot think deeply about their reading, and this can cause difficulties in the development of their abstract thinking skills. Learning to use digital devices will only stay in the short-term memory because, in reading activities, individuals do not need improvisation in absorbing existing information (Shin, 2014).

Based on this, writing activities need to be nurtured and honed because writing culture reflects an attitude of appreciating information stored in writing can be used at any time. Writing is considered as a memory bank, helpful in overcoming a person's memory 
weakness, especially for remembering ideas that have been put forward by people (lecturers, friends, or presenters in discussions) about various important things that become discussed in lectures (Syarif, Zulkarnaini, \& Sumarno, 2009).

Writing is not acquired spontaneously, but it requires a conscious effort to "write" sentences and consider ways to communicate and organize them. Thus, the role of the lecturer as an educator and motivator for students is indispensable in developing and increasing student writing activities.

\section{Mental Activity and Emotional Condition}

The final form of participation in learning activities is a mental activity. Mental activities that students can carry out as a form of participation in lectures can be done through remembering, responding, analyzing, solving problems, and making decisions. Based on the findings, it was obtained information that during online lectures, around $38.8 \%$ of students rarely remembered the material that had been delivered in lectures, so they rarely responded to questions in online classes. The average score obtained from mental activity in lessons was 2.75 or Moderate category. In addition, $52.2 \%$ of students often felt bored when asked to do mental activities such as remembering, responding, analyzing or solving problems. Nevertheless, $25.9 \%$ of the students felt that there was urgency or usefulness either from mental activities or the materials learned from lectures so that it could help them in making decisions and acting daily. The average score of emotional condition was 3.66, or the High category. Then, if the average of mental activity and students' emotional condition were calculated, the average score was 3.27 or Moderate category.

The results showed that in lectures, students rarely remembered the material delivered in classes. It had an impact on them rarely giving responses to materials and questions presented in online lessons. They emotionally felt bored carrying out various mental activities such as: remembering, responding, analyzing, or solving problems. However, they were also fully aware that the materials learned from lectures could help them make decisions and behave daily.

Mental activities carried out by students in lectures have enormous benefits for themselves, one of which is in decision making. It is a thought process carried out by individuals in evaluating alternatives and making choices (Santrock, 2014).

\section{Students' Attitudes Toward Online Lectures}

Taking the value of students' attitudes toward online learning was done by looking at the calculation of the frequency distribution, as shown in the table as follow.

Table 2. Frequency Distribution of Student Attitude to Online Lectures

\begin{tabular}{cccc}
\hline Attitude Category & Score & Frequency & Percentage \\
\hline Very Positive & $136-170$ & 7 & $8.4 \%$ \\
\hline Positive & $102-136$ & 43 & $50.4 \%$ \\
\hline Negative & $68-102$ & 35 & $41.2 \%$ \\
Very Negative & $34-68$ & 0 & $0 \%$ \\
\hline & & $\sum=85$ & 100 \\
\hline
\end{tabular}


Based on table 2, it describes that the student attitude to online lectures was very positive attitude category. The finding indicated that $8.4 \%$ or 7 students responded that online lectures were very effective, $50.4 \%$ or 43 students were effective, and $41.2 \%$ or 35 students were in the negative attitude category, meaning that lectures were ineffective.

The data obtained were in line with the interview results. It indicated that 77 students of 85 students stated that online lectures were considered effective enough to be carried out during the pandemic because apart from being able to be done in a relaxed and flexible manner from home but also as a way to avoid crowds and minimize the spread of the COVID-19 virus. However, it was undeniable that various obstacles made online lectures deemed less effective because technical and non-technical barriers were often encountered, such as signals, quotas, erratic weather and communication tools, which were inadequate. The various obstacles faced also affect the feelings shown by students during lectures, such as erratic weather caused unstable connections so that the students could not attend lectures completely. Enthusiasm for learning which was initially high due to unfavorable weather, could reduce enthusiasm for learning. It was not uncommon to find students who often felt annoyed and bored while attending lectures due to the learning methods used by lecturers were seen as monotonous and even often giving assignments rather than lecture material.

Meanwhile, to see the overall attitude of the students towards online lectures, it can be seen from the results of statistical calculations in the following table.

Table 3. Frequency Distribution of Students' Attitudes as a whole towards Online Lectures

\begin{tabular}{cc}
\hline Attitude Category & Score \\
\hline Very Positive & $11.560-14.450$ \\
\hline Positive & $8.670-11.560$ \\
\hline Negative & $5.780-8.670$ \\
\hline Very Negative & $2.890-5.780$ \\
\hline
\end{tabular}

Based on the students' distribution of each respondent's score as in the distribution table of the results of respondents' data collection, the total score for all respondents was 9.186. It meant that the overall attitude of the respondents towards online lectures was positive. The total score of the respondents was 9.186, which laid between 8.670 and 11.560 , which was the limit for the positive category score. This finding showed that overall, respondents viewd online lectures as effective.

The result of this research indicated that during the pandemic period, online lectures were one of the alternatives chosen in completing the rights and obligations of students to acquire learning. Riaz in Fitriyani, Fauzi, \& Sari (2020) stated that online learning was very useful in helping provide access to learning for everyone. It was effective to be applied, especially in higher education. Therefore, in developing it, it is necessary to pay attention to the ease of minimizing some of the obstacles that students often face. In addition, Rusdiana \& Nugroho, (2020) said that online lectures needed to use practical and easy teaching materials, which were carried out through several stages, starting from mapping, implementing online media and lectures, and evaluating through assignments. Besides, the 
implementation of online lectures also required an evaluation of college preparation and an evaluation from students.

\section{CONCLUSION}

During the Covid-19 pandemic, learning was carried out online in universities. To investigate the students' participation during taking online lectures, it could be seen in 5 activities, namely: (a) Visual Activity and Emotional Condition; this activity showed that students' participation had a moderate category with 2.61 of the average score in reading and reviewing books/lecture materials and they still had high participation to attend class; (b) Speaking (verbal) Activity and Emotional Condition; the average score was 3.44 which indicated that the students' participation of verbal activity was in the high category; (c) Listening Activity and Emotional Condition; this activity gained 3.26 of average score which showed the students' participation in listening was in moderate category; (d) Writing Activity and Emotional Condition; the average score of this activity was 2.76, which interpreted that the condition of students' writing activities was moderate category; (e) Mental Activity and Emotional Condition; the average of this activity was 3.27 or moderate category. In addition, the findings also found that overall, the students attitudes during online lectures as positive. Therefore, the research results indicated that online learning during the Covid-19 pandemic could be an effective way to be implemented, although, in practice, there were still some technical and non-technical obstacles. However, it is needed attention to minimize the obstacles faced by students so that the implementation of online learning requires an evaluation of the preparations from higher education.

\section{REFERENCES}

Abdillah. (2020). Hasil Survey Pembelajaran Online selama Masa Covid 19 Prodi S1 MPI dengan Responden 110 Mahasiswa SM II, IV dan VI 1. Prodi S1 MPI FITK.

Abdullah, M. Y., Bakar, N. R. A., \& Mahbob, M. H. (2012). Student's Participation in Classroom: What Motivates them to Speak Up? Procedia - Social and Behavioral Sciences, 51, 516-522. https://doi.org/10.1016/j.sbspro.2012.08.199.

Afandi, M., Chamalah, E., \& Wardani, O. P. (2013). Model dan Metode Pembelajaran. Semarang: Unissula Press.

Ali, M., Iskandar, R. A., Al-Amin, M. N., \& Langove, N. U. (2017). Strengthening the Academic Usage of Social Media: An Exploratory Study. Journal of King Saud University Computer and Information Sciences, 29(4), 553-561. https://doi.org/10.1016/j.jksuci.2016.10.002.

Anhusadar, L. O. (2020). Persepsi Mahasiswa PIAUD terhadap Kuliah Online di Masa Pandemi. Kindergarten: Journal of Islamic Early Childhood Education, 3(1), 44-58. https://doi.org/http://dx.doi.org/10.24014/kjiece.v3i1.9609.

Daeng, K., Amir, J., \& Hamsa, A. (2010). Pembelajaran Keterampilan Menyimak. Makassar: Badan Penerbit Universitas Negeri Makassar.

Dika, A., \& Sylejmani, K. (2012). The Level of Impact on Student Success of Participation in Lectures and Laboratory Exercises. Procedia - Social and Behavioral Sciences, 46, 2403-2408. https://doi.org/10.1016/j.sbspro.2012.05.493. 
Dohaney, J., de Róiste, M., Salmon, R. A., \& Sutherland, K. (2020). Benefits, Barriers, and Incentives for Improved Resilience to Disruption in University Teaching. International Journal of Disaster Risk Reduction, 50. https://doi.org/10.1016/j.ijdrr.2020.101691.

Fitriyani, Y., Fauzi, I., \& Sari, M. Z. (2020). Motivasi Belajar Mahasiswa pada Pembelajaran Daring selama Pandemi Covid-19. Profesi Pendidikan Dasar, 7(1), 121-132. https://doi.org/10.23917/ppd.v7i1.10973.

Kamah, I., Rachmanata, P., \& Rachmanata, D. P. (2002). Pedoman Pembinaan Minat Baca. Jakarta: Perpustakaan Nasional RI.

Kemendikbud. (2020). Biro Komunikasi dan Layanan Masyarakat Kementerian Pendidikan dan Kebudayaan. Retrieved from https://www.kemdikbud.go.id/main/blog/ 2020/03/mendikbud-terbitkan-se-tentang-pelaksanaan-pendidikan-dalam-masa -darurat-covid19.

Muhidin, S. A., \& Abdurahman, M. (2007). Analisis Korelasi, Regresi dan Jalur Dalam Penelitian. Bandung: CV. Pustaka Setia.

Muslih, Y. N., Wibowo, M. E., \& Purwanto, E. (2017). Konseling Behavioral Menggunakan teknik Kontrak Perilaku dengan Students' Logbook untuk Meningkatkan Minat Membaca Siswa. Jurnal Bimbingan Konseling, 6(1), 34-43. https://doi.org/10.15294/JUBK.V6I1.17432.

Najib, W. (2017). Analisis Penerapan Pembelajaran Daring pada Mata Kuliah Jaringan Komputer dengan Metode Massive Open Online Course (MOOC). ResearchGate, 110. Retrieved from https://www.researchgate.net/publication/328715713_ Analisis_Penerapan_Pembelajaran_Daring_Pada_Mata_Kuliah_Jaringan_Komputer _dengan_Metode_Massive_Open_Online_Course_MOOC.

Nawawi, Qura, U., \& Rahmayanti, I. (2017). Keterampilan Berbicara sebagai Suatu Keterampilan Berbahasa. Jakarta: Uhamka Press.

Prihatin, E. (2014). Manajemen Peserta Didik. Bandung: Alfabeta.

Rusdiana, E., \& Nugroho, A. (2020). Respon pada Pembelajaran Daring bagi Mahasiswa Mata Kuliah Pengantar Hukum Indonesia. Integralistik, 31(1), 1-12. https://journal.unnes.ac.id/nju/index.php/integralistik/article/view/21834/.

Safrida, L. N., Ambarwati, R., \& Albirri, E. R. (2017). Partisipasi Mahasiswa dalam Pembelajaran Kooperatif Berdasarkan Lesson Partisipasi Mahasiswa dalam Pembelajaran Kooperatif Berbasis Lesson Study (Undergraduate Students Participation in Cooperative Learning Based on Lesson Study). Jurnal Edukasi, IV(3), 54-58. https://doi.org/10.19184/jukasi.v4i3.6304.

Samsudi. (2009). Disain Penenlitian Pendidikan (Edisi kedua). Semarang: Universitas Negeri Semarang Press.

Santrock, J. W. (2014). Psikologi Pendidikan. Jakarta: Salemba Humanika.

Sardiman, A. . (2011). Interaksi dan Motivasi Belajar Mengajar. Jakarta: Rajawali Press.

Shin, Y.-J. (2014). Mendidik Anak di Era Digital Kita Menangkal Efek Buruk Teknologi terhadap Anak (kesatu). Jakarta: Naoura Books.

Slamet. (2003). Belajar dan Faktor-faktor yang Mempengaruhinya. Jakarta: Rineka Cipta.

288 LENTERA PENDIDIKAN : JURNAL ILMU TARBIYAH DAN KEGURUAN, VOL. 24 NO. 2 DESEMBER 2021: 276-289 
Syarif, E., Zulkarnaini, \& Sumarno. (2009). Pembelajaran Menulis. Jakarta: Departemen Pendidikan Nasional Direktorat Jenderal Mutu Pendidik dan Tenaga Kependidikan Pusat Pengembangan dan Pemberdayaan Pendidikan dan Tenaga Kependidikan Bahasa.

UNESCO. (2020). School Closures Caused by Coronavirus (Covid-19). In Unesco. Retrieved from https://en.unesco.org/themes/education-emergencies/coronavirus-schoolclosures. 